\title{
Impacts of climate change on annual diameter increment of natural Calabrian pine (Pinus brutia Ten.) forests in Kahramanmaras
}

\author{
Mahmut Reis $^{\mathrm{a}, *(\mathbb{D}) \text {, Hurem Dutal }}{ }^{\mathrm{a}}$, Bülent Abız ${ }^{\mathrm{a}}$, Seda Tat ${ }^{\mathrm{a}}$, Ahmet Reis ${ }^{\mathrm{a}}$
}

\begin{abstract}
The effects of global warming on climate change have been recognized in global scale and it is expected that these effects will become even more obvious in near future. The climate change, especially in arid, semi-arid, and semi-humid regions, may result in detrimental effects on forests and water resources. Turkey is among the most affected countries from climate change due to located in Mediterranean region. With the global climate change, dams and ponds also influence on tree growth. This study was carried out in Menzelet watershed dam located in Kahramanmaras, Turkey. Menzelet dam was established during 1980-1989 and water deposition started in 1990. The climate of research area is semi-arid and characterized by extreme summer drought. The purpose of this study was to investigate the local climate effects on diameter increments resulted by Menzelet Dam Lake on the naturally distributed Calabrian pine (Pinus brutia Ten.) forests. Therefore, sampling areas were chosen from two different places namely as dam site and control site. Sample plots in dam site and control site were selected from the same stand structure and have the same properties such as site index, altitude, age distribution classes and aspect. Increment cores were taken from 20 Pinus brutia trees using increment borer at breast height $(1.30 \mathrm{~m})$ in each sample plots and two increment cores were taken from each tree. WinDENDRO software package was used on the measurement and determination of annual diameter increment. Annual diameter increment of trees in dam site and control site were compared with independent t test using SPSS 20.0 statistical program. The relationships between annual diameter increment and climatic factors such as temperature and precipitation were evaluated using Pearson correlation analysis. According to results, there is a statistically significant difference between average annual diameter increment in dam site and control site and dam influenced forest areas positively with respect to annual diameter increment. The values of the mean annual diameter increment of the trees in dam site are greatly higher than trees in control site. According to correlation analysis, temperature increase negatively affects annual diameter increment in control site. Important increase or decrease of annual total rainfall cause more significant changes in annual diameter increment in control site compare to dam site.
\end{abstract}

Keywords: Annual diameter increment, Calabrian pine, Climate change, Menzelet dam

\section{İklim değişikliğinin Kahramanmaraş’ta bulunan doğal Kızılçam (Pinus brutia Ten.) ormanlarının yıllık çap artımı üzerine etkileri}

\begin{abstract}
Özet: Küresel ısınmanın iklim değişikliği üzerindeki etkileri küresel ölçekte kabul edilmiş olup bu etkilerin yakın gelecekte daha da hissedilir hale geleceği beklenmektedir. İklim değişikliği özellikle kurak, yarı kurak ve yarı nemli bölgelerde ormanlar ve su kaynakları üzerinde olumsuz etkilere neden olabilmektedir. Aynı zamanda bir Akdeniz ülkesi olan Türkiye iklim değişikliğinden en fazla etkilenmesi beklenen ülkeler arasında yer almaktadır. Küresel iklim değişikliği ile birlikte barajlar ve göller de ağaçların büyümesi üzerinde etkili olmaktadır. Bu çalışma Türkiye'nin Kahramanmaraş şehrinde bulunan Menzelet baraj havzasında gerçekleştirilmiştir. Menzelet barajı 1980-1989 yılları arasında inşa edilmiş ve 1990 yılında su toplamaya başlamıştır. Yarı kurak iklim özelliğine sahip olan araştırma alanında aşırı yaz kuraklıkları görülmektedir. Bu çalışmanın amacı Menzelet baraj gölünün neden olduğu lokal iklim koșullarının alanda doğal olarak yayılıș gösteren kızılçam ormanlarının çap artımı üzerindeki etkilerinin incelenmesidir. Bu nedenle baraj ve kontrol bölgesi olarak adlandırılan iki farklı yerden örneklem alanları seçilmiştir. Seçilen örneklem alanları meşcere yapısı ve bonitet, yükseklik, yaş dağılım sınıfı ve bakı bakımından aynı özelliklere sahiptir. Artım burguları yardımıyla her bir ağaçtan 2 adet olmak üzere her bir örneklem alanındaki 20 kızılçam ağacının göğüs yüksekliğinden artım çubukları alınmıștır. Yıllık çap artımlarının belirlenmesinde WinDENDRO bilgisayar programı kullanılmıștır. Baraj ve kontrol alanındaki ağaçların çap artımları SPSS 20.0 istatistik programı kullanılarak bağımsız t-testi ile karşılaştırılmıştır. Yııllık çap artımı ile sıcaklık ve yağış gibi iklimsel faktörler arasındaki ilişkiler Pearson korelasyon analizi ile incelenmiştir. Sonuçlara göre, yıllık ortalama çap artımı açısından baraj alanı ile kontrol alanı arasında istatistiksel olarak anlamlı bir farklılık vardır ve baraj, kızılçam ormanlarının yıllık ortalama çap artımı üzerinde olumlu bir etkiye sahiptir. Baraj alanında bulunan ağaçların yıllık ortalama çap artım değerleri kontrol alanındaki değerlere nazaran oldukça yüksektir. Korelasyon analizi sonuçlarına göre, sıcaklık artışı kontrol alanındaki yıllık çap artımını olumsuz olarak etkilemektedir. Yıllık toplam yağıştaki önemli düzeydeki artış veya azalmalar baraj alanıyla karşılaştırıldığında kontrol alanındaki yıllık çap artımında daha önemli değişikliklere neden olmaktadir.
\end{abstract}

Anahtar kelimeler: Yıllık çap artımı, Kızılçam, İklim değiş̧ikliği, Menzelet barajı

$\triangle$ a Kahramanmaras Sutcu Imam University, Faculty of Forestry, Department of Forest Engineering, 46100 Kahramanmaras, Turkey

Corresponding author (İletişim yazarı): mreis@ksu.edu.tr

$\checkmark \quad$ Received (Gelis tarihi): 19.03.2018, Accepted (Kabul tarihi): 04.06.2018
Citation (Atıf): Reis, M., Dutal, H., Abız, B. Tat, S., Reis, A., 2018. Impacts of climate change on annual diameter increment of natural Calabrian pine (Pinus brutia Ten.) forests in Kahramanmaras. Turkish Journal of Forestry, 19(3): 219-225.

DOI: $\underline{10.18182 / \mathrm{tjf} .407487}$ 


\section{Introduction}

Ecological factors have an effect on tree growth and the most important ecological factors are climatic parameters. Especially, temperature and precipitation are most commonly correlated with tree species distribution, diameter and height growth (Fritts, 1976). It is quite difficult to determine the climate effects on plants, as plants are influenced by numerous environmental factors. Although various studies related impacts of climate change on trees have been carried out, the greater part of these studies are related to species and geographic distribution of plants. The impact of climate change takes place over a long period while its effects on diameter and height growth emerge in a short period (Fritts, 1976).

Climate change is defined as increasing global temperature and changing precipitation pattern (Karabulut and Cosun, 2009). In the world, average precipitation has increased indistinctly and average temperature has also increased by $0.6 \pm 0.2{ }^{\circ} \mathrm{C}$ in the last 100 years (Barnett, 2001; IPCC, 2001; Levitus, 2001). According to data obtained from climatic models, it is estimated that temperature will increase by $1.4-5.8{ }^{\circ} \mathrm{C}$ in $2071-2100$ due to increasing atmospheric carbon dioxide (IPCC, 2001). Observed heating tendency in global average surface temperature has not an equal geographic distribution around the world, and particularly long term heating tendency takes place more in middle and high latitudes (40-70 degree north) (IPCC, 2007). Especially, Mediterranean region is influenced significantly by climate change (Bertini et al., 2011).

The most important factor affecting tree growth in Mediterranean region is summer drought (Mooney, 1982). Generally conifer forests have several ways to survive under the drought conditions with less growth rates compare to temperate forests (Margaris and Mooney, 1981). In this region, water availability will also decrease in the near future due to increase of temperatures, decrease of precipitation and increase of evapotranspiration (IPCC, 2001). Height and diameter increments are typical growth characteristics of trees and they are directly related to temperature and precipitation (Petras and Mecko, 2011). Effects of water availability on diameter increment have also been determined in the Mediterranean region (Ogaya et al., 2003). Because precipitation and temperature values affect available water capacity, change of annual precipitation and temperature by years affects annual ring width (Costa et al., 2001). Water is a basic chemical component of most plant cells and also primary requirement for photosynthesis. Lack of water availability in soil influences directly tree growth in several ways such as decrease of photosynthetic capacity and diameter increment (Chapin, 1980).

Dendrochronological studies based on tree rings are generally used to examine the climate effects on diameter increment of trees (Grogan and Schulze, 2012). These studies are important for investigating long term responses of trees because tree ring data provides necessary information to evaluate changes in tree growth (Knapp et al., 2001). Global warming and climatic variability such as precipitation and temperature cause changes in tree growth patterns as a result of climate response of forests in Mediterranean region. There are several studies related tree growth based on climatic variables such as temperature and precipitation (Feliksik and Wilczynski, 2009; Rybnicek et al., 2009; Kazmierczak and Zawieja, 2014). These studies provide information how tree growth responds to large scale climatic variables. However, the effects of local weather variability caused by dam on tree growth are scarce.

The aim of this study was to investigate, using a dendroclimatological approach, the local climate effects on diameter increments resulted by Menzelet Dam on the naturally distributed Calabrian pine forests in the Eastern Mediterranean part of Turkey. This study was also to analyze temporal variability of diameter increments and climatic variables such as temperature and precipitation effects.

\section{Material and method}

\subsection{Study area}

This study was carried out in Calabrian pine forest surrounding Menzelet dam which is located in north of Kahramanmaras city in the Eastern Mediterranean part of Turkey. The study area is located $37^{0} 38^{\prime} \mathrm{N}$ latitude, $36^{\circ} 49^{\prime} \mathrm{E}$ longitude, generally south facing, average slope \% 30 and about 720 altitudes. Kahramanmaras city has three different geographic regions (Mediterranean region, east and southeastern Anatolia region) and mainly degraded Mediterranean climate characteristics among three different climates due to its geographic location. Generally, summers are warm and arid, winters are cold and snowy. In the study area, average annual precipitation is over $700 \mathrm{~mm}$ and precipitation is usually in winter and spring seasons. The average annual temperatures is $16.7^{\circ} \mathrm{C}$, while minimum and maximum temperatures are $-9.6{ }^{\circ} \mathrm{C}$ (February) and $45.2{ }^{\circ} \mathrm{C}$ (July), respectively (TSMS, 2012).

According to Thornthwaite climate classification, the study areas has (C2B3's2a') sub-humid, mesothermal and large water deficiency in summer climate type according to water balance. When monthly changes of precipitation and potential evapotranspiration are examined, there is water deficiency in June- October and water surplus in JanuaryApril (Figure 1). The climate of the study area is semi-arid and characterized by extreme summer drought according Erinc formula revised by Kantarc1 (Usta et al., 2009).

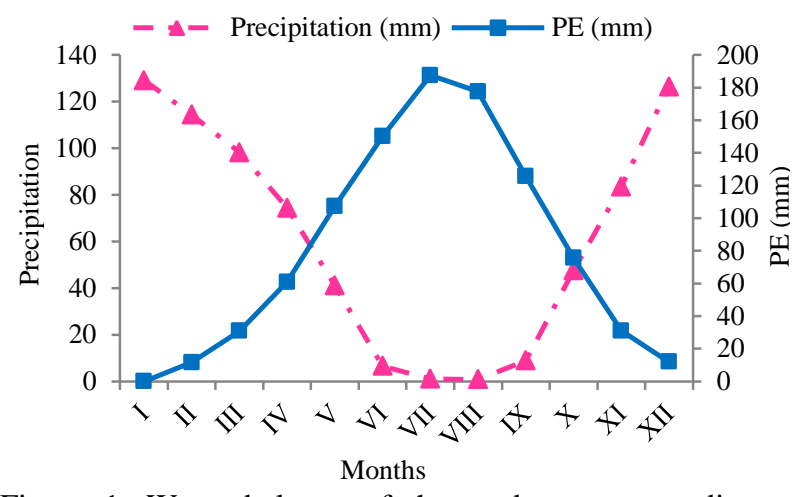

Figure 1. Water balance of the study area according to thornthwaite method 
Study area is located in Mediterranean region which is one of the three large flora regions (Ansin, 1983). Dominant forest tree species are Calabrian pine, black pine (Pinus nigra var. pallasiana Schneid), Taurus cedar (Cedrus libani A. Rich.), Persian oak (Quercus brantii Lindl.), and juniper (Juniperus sp.) in study area. Menzelet dam was built during 1980-1989 and water deposition started in 1990. Menzelet dam, located in $26 \mathrm{~km}$ northwestern of Kahramanmaras, has $136,50 \mathrm{~m}$ height from stream bed, and its reservoir volume and area are $1950 \mathrm{hm}^{3}$ and $42 \mathrm{~km}^{2}$, respectively (GDSHW, 2016).

\subsection{Method}

This study was carried out in Menzelet watershed dam located in Kahramanmaras, Turkey. Menzelet dam has begun to retain water since 1990 . Field survey was carried out in the summer of 2012. Therefore, 22 years period in between 1990 and 2011 was investigated in the present study. We took two sample plots and one of them is control site not influenced by dam and the other is under the influence of dam. Sample plots in dam site and control site were selected from the same stand structure and have the same properties such as site index, altitude, age distribution classes and aspect (Table 1). Increment cores were taken from Calabrian pine trees using increment borer at breast height $(1.30 \mathrm{~m}) .20$ trees were selected in each sample plots and two increment cores were taken from each tree. Increment cores were inserted into labeled paper straws and samples were dried, mounted, and fine-sanded with gradually $120-800$ grit sandpapers. According to standard dendrochronological techniques, samples were crossdated in the laboratory (Swetnam, 1985; Stokes and Smiley, 1996). Then, each increment core was scanned at 3200 dpi using scanner to be measured to the nearest $0.01 \mathrm{~mm}$ sensitivity of the annual ring widths of each core using image analysis program WinDENDRO (Regent Instruments Canada Inc., 2009).

By using SPSS 20.0 statistical program, independent $t$ test was used to determine whether or not there were any significant differences between average annual diameter increment of trees in dam site and control site. Whether or not there are statistically significant differences between trees in control site and trees influenced by dam in terms of diameter change year by year was also determined using independent $\mathrm{t}$ test. The relationships between annual diameter increment and climatic factors such as temperature and precipitation were evaluated using Pearson correlation analysis.

\section{Results and discussion}

The mean annual diameter increment for trees in dam site and control site are shown in Figure 2. As shown in this figure, obvious differences in the annual diameter increment among the growing years for the trees in dam site as well as control site were determined. According to results of independent $\mathrm{t}$ test, there is a statistically significant difference between average annual diameter increment in dam site and control site (Table 2). This means that dam influenced forest areas positively with respect to annual diameter increment at the significant level of $\mathrm{P}<0.001$. The values of the mean annual diameter increment of the trees in dam site are greatly higher than trees in control site. According to results, average annual diameter increment was $1.27 \mathrm{~cm}$ in dam site and $0.98 \mathrm{~cm}$ in control site within 22 years. Minimum and maximum annual diameter increments were $1.07 \mathrm{~cm}$ in 2002 and $1.48 \mathrm{~cm}$ in 1995, respectively in dam site.

Table 1. Site descriptions of study area

\begin{tabular}{lcccc}
\hline Sample plot & $\begin{array}{c}\text { Altitude } \\
(\mathrm{m})\end{array}$ & Aspect & $\begin{array}{c}\text { Slope } \\
(\%)\end{array}$ & $\begin{array}{c}\text { Number of } \\
\text { increment cores }\end{array}$ \\
\hline Dam site & 720 & South & 29 & 40 \\
Control site & 735 & South & 32 & 40 \\
\hline
\end{tabular}

Table 2. The results of independent $t$ test for the average annual diameter increment in dam site and control site

\begin{tabular}{lcccc}
\hline & Mean & Std. Deviation & $\mathrm{t}$ & $\mathrm{p}$ \\
\hline Dam site & 1.271 & 0.122 & \multirow{2}{*}{5.792} & \multirow{2}{*}{$.000^{*}$} \\
Control site & 0.985 & 0.197 & & \\
\hline $\mathrm{P}<0.05$ & & & &
\end{tabular}

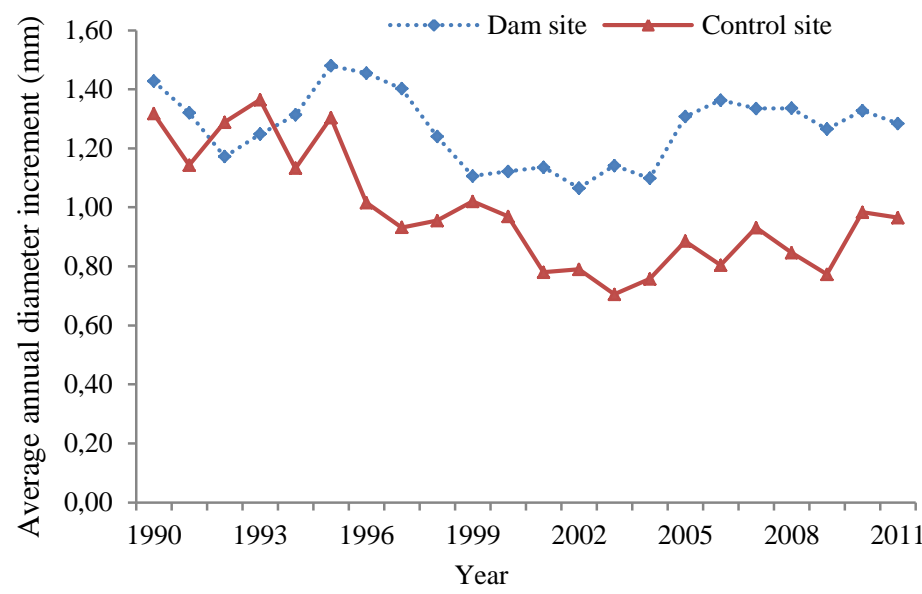

Figure 2. Average annual diameter increment of Pinus brutia in dam site and control site 
Figure 3 shows the percent increase in average annual diameter increment of pine trees in dam site and control site for 22 growing years. Average increase in annual diameter increment for the same years is about $29.0 \%$. The values vary from $8.4 \%$ to $69.5 \%$ for the 22 growing years, from 1990 to 2011. The greatest percent increase in the annual diameter increment is for the years of 2006, followed by $63.6 \%$ in $2009,61.9 \%$ in 2003 and $57.8 \%$ in 2008, respectively.

The results of independent $t$ test for the annual diameter increment of trees in both control site and dam site are showed in Table 3. According to results, there are significant differences in 1996, 1997 and 2001-2009 periods at the confidence level of $95 \%$ with respect to annual diameter increment in dam site and control site. However, there is no significant difference in first six years period from 1990 to 1995 . The reason of this situation was that the positive effect of dam on diameter increment of trees emerges after 6 years from retaining water by dam. In other words, dam has begun to influence local ecologic properties after 6 years ever since it begun to retain water. Annual diameter increments in both sites were nearly similar in 1999. The reason was that precipitation amount in this year was far below the average value and the lowest annual total precipitation observed within 22 years $(442.7 \mathrm{~mm})$ in Kahramanmaras.

Table 3. The results of independent $t$ test for the annual diameter increment in dam site and control site on the basis of years

\begin{tabular}{cccccc}
\hline Year & \multicolumn{1}{c}{$\mathrm{t}$} & Sig.(2-tailed) & Year & $\mathrm{t}$ & Sig.(2-tailed) \\
\hline 1990 & .521 & .607 & 2001 & 2.619 & .015 \\
1991 & .860 & .398 & 2002 & 2.081 & .048 \\
1992 & -.695 & .493 & 2003 & 2.835 & .009 \\
1993 & -.617 & .543 & 2004 & 2.089 & .047 \\
1994 & 1.107 & .279 & 2005 & 2.082 & .048 \\
1995 & .635 & .531 & 2006 & 3.283 & .003 \\
1996 & 2.132 & .043 & 2007 & 2.468 & .021 \\
1997 & 2.845 & .009 & 2008 & 2.441 & .022 \\
1998 & 1.795 & .085 & 2009 & 2.750 & .011 \\
1999 & .408 & .686 & 2010 & 1.648 & .112 \\
2000 & .815 & .423 & 2011 & 1.989 & .058 \\
\hline
\end{tabular}

According to Karabulut and Cosun (2009), the number of rainy days was 119 in 1996, while it was 79 days in 1997 with considerable decrease in Kahramanmaras between 1975 and 2005. Besides, number of rainy days decreased 11 days within 30 years in the Kahramanmaras. Change of annual precipitation affects annual ring width (Costa et al., 2001) and lack of water availability in soil influences directly tree growth in several ways (Chapin, 1980). It was seen that diameter increment of trees in both sites decreased due to decrease in number of rainy days in 1997. Nevertheless there was statistically difference between dam site and control site in terms of diameter increment in the same year. Main reason of statistically difference was that stands around the dam were less influenced than those in control site in terms of annual diameter increment despite decrease in number of rainy days.

Turkes et al., (2002) reported that temperature increase in Kahramanmaras was $1.03{ }^{\circ} \mathrm{C}$ within $1975-2005$ and temperature increase is more pronounced in the last 22 years. Maximum average annual temperature was $18.89{ }^{\circ} \mathrm{C}$ in 2010 , while minimum average annual temperature was $15.19{ }^{\circ} \mathrm{C}$ in 1992 . Minimum average annual precipitation was $15.19{ }^{\circ} \mathrm{C}$ in 1992 while the minimum total annual precipitation was $442.70 \mathrm{~mm}$ in 1999. A statistically difference was not determined in terms of diameter increment between both sites in 2010 and 2011. The most important reason was that the highest summer temperature was observed in 2010. Even though any difference was not statistically determined in 2010 and 2011, diameter increment of stands around the dam was relatively more than those in control site due to positive hydrologic impacts of the dam.

According to correlation analysis, it was determined that precipitation had positive effect on diameter increment, while temperature had negative effect. Although precipitation had positive effect on diameter increment, this effect was not statistically significant. A climatological analysis based on tree ring chronologies figured out that there are commonly low correlations between total precipitation and diameter increment in the dry season (Worbes, 1999).

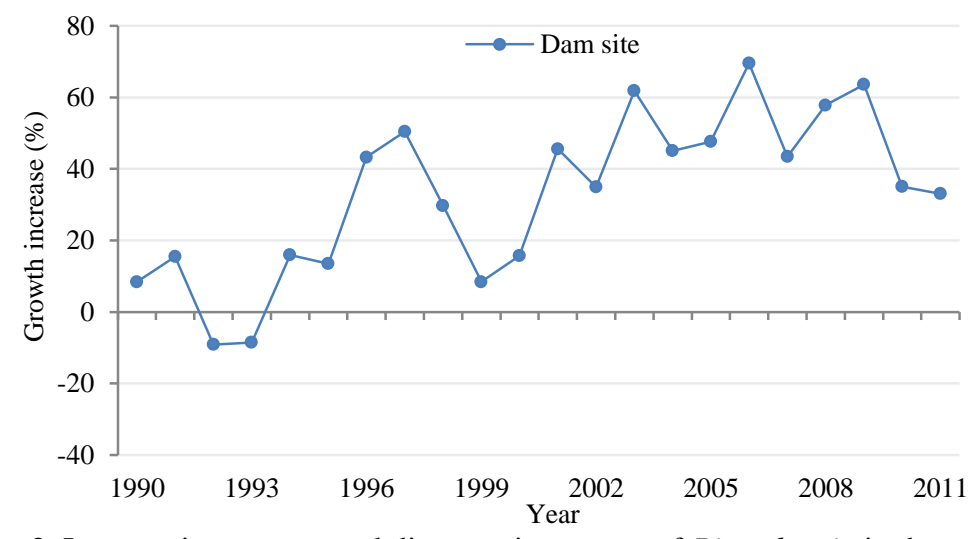

Figure 3. Increase in mean annual diameter increment of Pinus brutia in dam site 
It was understood that temperature had statistically significant correlation on diameter increment at the confidence level of $95 \%$ in control site, but forest in dam site were less affected by temperature as compared with control site (Table 4). Increased temperature might cause more drought problems which have negative effects on annual diameter increment. Annual diameter increment based on tree ring series for the past 90 years showed a strong decrease with increasing drought and temperature and productivity in forest ecosystem in Europe reduced in the very warm and dry summer 2003 (Solberg et al., 2009; Barber et al., 2000; Ciais et al., 2005).

Temperature rise negatively affects annual diameter increment in control site although it does not affect annual diameter increment in dam site especially after 1996 (Figure 4). In other words, forests in control site were more affected than forest in dam sites due to temperature rise. Important increase and decrease of annual total rainfall cause more significant changes in annual diameter increment in control site compare to dam site (Figure 5). This situation can be explained that local climate effects tolerated important changes in precipitation and temperature.

Precipitation is not the only factor determining annual diameter increment. High temperature can be considered as another factor affecting tree growth. It promotes drought stress and reduces water availability in the soil due to high evapotranspiration. The key factor affecting the tree growth at lower altitudes is precipitation (Larcher, 1988). The decrease in precipitation at the dry season causes low water potential in soil (Franco, 1979).

Table 4. The results of Pearson correlation analysis for the relationships between annual diameter increment and climatic factors

\begin{tabular}{|c|c|c|c|c|}
\hline & & $\begin{array}{c}\text { Average } \\
\text { temperature }\end{array}$ & $\begin{array}{c}\text { Average } \\
\text { precipitation }\end{array}$ & $\begin{array}{c}\text { Diameter } \\
\text { increment } \\
\text { in dam site }\end{array}$ \\
\hline \multirow{2}{*}{$\begin{array}{l}\text { Average } \\
\text { precipitation }\end{array}$} & $\begin{array}{l}\text { Pearson } \\
\text { correlation }\end{array}$ & -.032 & & \\
\hline & $\begin{array}{l}\text { Sig. } \\
\text { (2-tailed) }\end{array}$ & .889 & & \\
\hline \multirow{2}{*}{$\begin{array}{l}\text { Diameter } \\
\text { increment } \\
\text { in dam site }\end{array}$} & $\begin{array}{l}\text { Pearson } \\
\text { correlation }\end{array}$ & -.292 & .203 & \\
\hline & $\begin{array}{l}\text { Sig. } \\
\text { (2-tailed) }\end{array}$ & .187 & .366 & \\
\hline \multirow{2}{*}{$\begin{array}{l}\text { Diameter } \\
\text { increment } \\
\text { in control site }\end{array}$} & $\begin{array}{l}\text { Pearson } \\
\text { correlation }\end{array}$ & $-.512^{*}$ & .182 & $.674^{* * *}$ \\
\hline & $\begin{array}{l}\text { Sig. } \\
\text { (2-tailed) }\end{array}$ & .015 & .418 & .001 \\
\hline
\end{tabular}

* Correlation is significant at the 0.05 level (2-tailed); ** Correlation is significant at the 0.01 level (2-tailed)

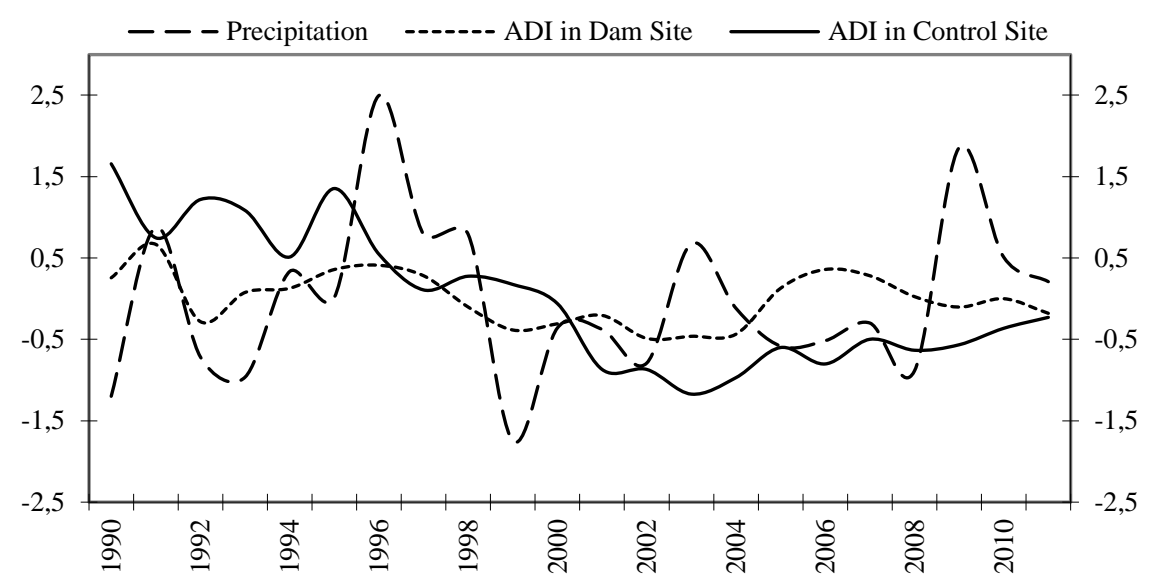

Figure 4. Comparison of precipitation and annual diameter increment (ADI) in dam site and control site

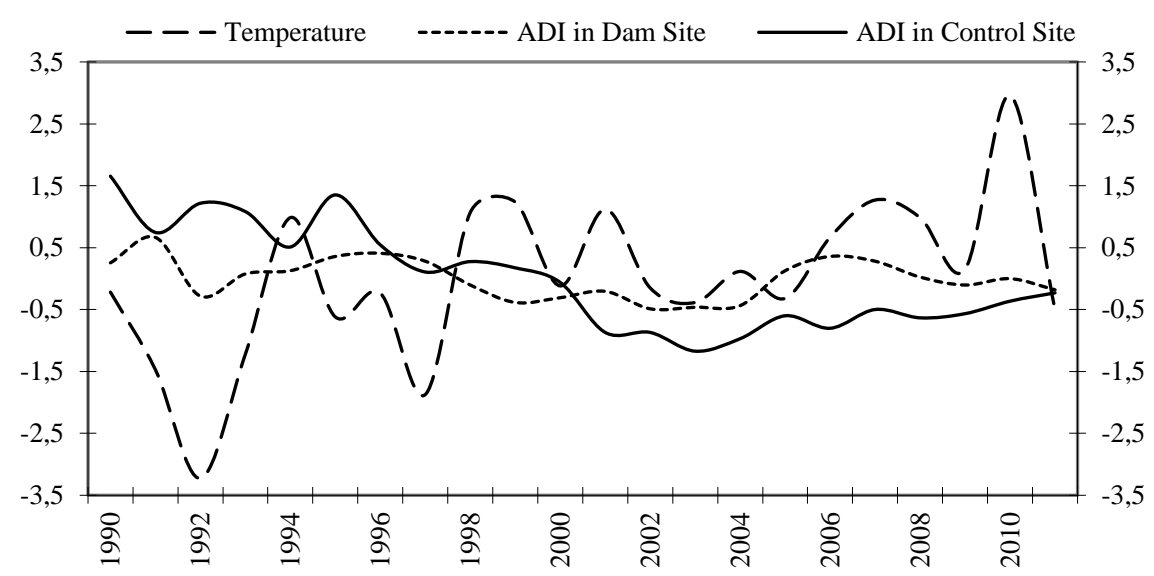

Figure 5. Comparison of temperature and annual diameter increment (ADI) in dam site and control site 
Climate is strongly related with local site conditions (Feliksik and Wilczynski, 2009). Annual diameter increments of Douglas fir mainly depend on precipitation in semiarid regions. However, an extremely high temperature has a negative effect on tree growth due to increasing transpiration (Fritts, 1974; Biondi, 1997). Temperature is the main factor affecting tree growth in the mountain areas (Rybnicek et al., 2009). Excessively low temperatures related with drought can negatively influence annual diameter increment at the highest mountain altitudes (Cermak, 2007).

\section{References}

Ansin, R., 1983. The floristic regions and the major vegetation types of Turkey. Karadeniz Technical University, Faculty of Forestry Journal, 6(2): 318-339.

Barber, V.A., Juday, G.P., Finney, B.P., 2000. Reduced growth of Alaskan white spruce in the twentieth century from temperature-induced drought stress. Nature, 405: 668-673.

Barnett, T.P., 2001. Detection of anthropogenic climate change in the world's oceans. Science, 292: 270-274.

Bertini, G., Amoriello, T., Fabbio, G., Piovosi, M., 2011. Forest growth and climate change: evidence from the ICP-Forest intensive monitoring in Italy. iForestBiogeosciences and Forestry, 4:262-267.

Biondi, F., 1997. Evolotionary and moving response functions in dendroclimatology. Dendrochronologia, 15: 139-150.

Cermak, P., 2007. Defoliace a radialni rüst jako ukazetele vitality smrku ztepileho. Lesnicka Prace, 86: 14-15.

Chapin , F.S., 1980. The mineral nutrition of wild plants. Annu. Rev. Ecol. Syst., 11: 233-260.

Ciais, P., Reichstein, M., Viovy, N., Granier, A., Ogee, J., Allard, V., Aubinet, M., Buchmann, N., Bernhofer, C., Carrara, A., Chevallier, F., De Noblet, N., Friend, A.D., Friedlingstein, P., Grunwald, T., Heinesch, B., Keronen, P., Knohl, A., Krinner, G., Loustau, D., Manca, G., Matteucci, G., Miglietta, F., Ourcival, J.M., Papale, D., Pilegaard, K., Rambal, S., Seufert, G., Soussana, J.F., Sanz, M.J., Schulze, E.D., Vesala, T., Valentini, R., 2005. Europe-wide reduction in primary productivity caused by the heat and drought in 2003. Nature, 437: 529-533.

Costa, A., Pereira, H., Oliveira, A., 2001. A dendroclimatological approach to diameter growth in adult cork-oak trees under production. Trees, 15: 438443.

Feliksik, E., Wilczynski, S., 2009. The effect of climate on tree-ring chronologies of native and nonnative tree species growing under homogenous site conditions. Geochronometria, 33:49-57.

Franco, W., 1979. Die wassesrdynmamik einiger waldstandorte der West-Llanos Venezuelas und ihre Beziehung zur Saisonalitat sde des Laubfalles. Dissertation. Univerversitat Göttingeen, Germany.

Fritts, H.C., 1974. Relationships of ring widths in arid-site conifers to variations in monthly temperature and precipitation. Ecological Monograph, 44: 411-440.

Fritts, H.C., 1976. Tree rings and climate. Academic Press, London.
GDSHW, 2016. General directorate of state hydraulic works, facility of 20 . Kahramanmaras Regional Directorate, Kahramanmaras.

Grogan, J., Schulze, M., 2012. The impact of annual and seasonal rainfall patterns on growth and phenology of emergent tree species in southeastern Amazonia, Brazil. Biotropica, 44 (3): 331-340.

IPCC, 2001. Climate Change. In: Houghton, J.T., Ding, Y., Griggs, D.J., Nouguer, M., van der Linden, P.J., Dai, X., Maskell, K., Jonson, J.A. (Eds.), The Scientific Basis. Contribution of Working Group I in the Third Assessment Report of the Intergovernmental Panel on Climate Change. Cambridge University Press, Cambridge.

IPCC, 2007. Climate Change. Synthesis Report, Contribution of Working Groups I, II and III to the Fourth Assessment Report of the Intergovernmental Panel on Climate Change, Core Writing Team, Pachauri, R.K. and Reisinger, A. (Eds.), IPCC, Geneva, Switzerland.

Karabulut, M., Cosun, F., 2009. Trend analyses of precipitations in Kahramanmaras city. Journal of Geography Science, 7 (1): 65-83.

Kazmierczak, K., Zawieja, B., 2014. The influence of weather conditions on annual height increments of Scots pine. Biometrical Letters, 51 (2):143 - 152.

Knapp, P.A., Soule, P.T., Grissino-Mayer, H.D., 2001. Detecting potential regional effects of increased atmospheric $\mathrm{CO}_{2}$ on growth rates of western juniper. Global Change Biology, 7:903-917.

Larcher, W., 1988. Fyziologicka ekologie rostlin. Praha, Academia, 361.

Levitus, S., 2001. Anthropogenic warming of earth's climate system. Science, 292: 267-270.

Margaris, N.S., Mooney, H.A., 1981. Components of Productivity of Mediterranean-Climate Regions, Basic and Applied Aspects. Junk Publishers, The Hague/Boston/London.

Mooney, H.A., 1982. Habitat, Plant Form, and Plant Water Relations in Mediterranean-Climate Regions. Ecologia Mediterranea, 8: 481-488.

Ogaya, R., Peñuelas, J., Martínez-Vilalta, J., Mangirón, M., 2003. Effect of drought on diameter increment of Quercus ilex, Phillyrea latifolia, and Arbutus unedo in a holm oak forest of NE Spain. Forest Ecology and Management, 180: 175-184.

Petras, R., Mecko, J., 2011. Effect of climatic factors on the dynamics of radial increments of Norway spruce, European beech and sessile oak. Journal of Forest Science, 57(7): 293-302.

Regent Instruments Canada Inc. 2009. WINDENDRO for Tree-ring Analysis.

Rybnicek, M., Cermak, P., Kolar, T., Premyslovska, E., Zıd, T., 2009. Influence of temperatures and precipitation on radial increment of Orlicke Hory Mts. Spruce Stands at Altitudes over $800 \mathrm{~m}$ a.s.l. Journal of Forest Science, 55 (6): 257-263. 
Solberg, S., Dobbertin, M., Reinds, G.J., Lange, H., Andreassen, K., Fernandez, P.G., Hildingsson, A., Vries, W., 2009. Analyses of the impact of changes in atmospheric deposition and climate on forest growth in European monitoring plots: A stand growth approach. Forest Ecology and Management, 258 (8): 1735-1750.

Stokes, M.A., Smiley, T.L., 1996. An Introduction to TreeRing Dating. Chicago, IL: University of Chicago Press.

Swetnam, T.W., 1985. Using Dendrochronology to Measure Radial Growth of Defoliated Trees. USDA Forest Service, Cooperative State Research Service. Agriculture Handbook No: 639, Washington.

TSMS, 2012. Turkish State Meteorological Service, 19752012, Ankara.
Turkes M., Sümer, U.M., Demir, İ., 2002. Re-evaluation of trends and changes in mean, maximum and minimum temperatures of Turkey for the period 1929-1999. International Journal of Climatology, 22: 947-977.

Usta, A., Altun, L., Güvendi, E., Yener, İ., 2009. The relationship with the distribution of forests and regional climate analysis of Turkey. 1. National Drought and Desertification Symposium. Konya, Turkey. s. 171-180.

Worbes, M., 1999. Annual growth rings, rainfall-depend growth and long-term growth patterns of tropical trees from the Caparo Forest Reserve in Venezuela. Journal of Ecology, 87: 391-403. 